\title{
Impact of employee age on the safe performance of production tasks
}

\author{
Małgorzata Rembiasz ${ }^{1, *}$ \\ ${ }^{1}$ Poznań University of Technology, Faculty of Management Engineering, Chair of Entrepreneurship \\ and Business Communication, 11 Strzelecka St., 60-965 Poznań, Poland
}

\begin{abstract}
The number of occupational accidents reported in Polish industry and the extent of the resulting losses show that safety is critical for the effective performance of production tasks. In view of such high accident rates, a pressing need has been recognized for identifying and undertaking improvement measures. The factors which require a response to secure adequate safety levels for the labor force include worker age. Such age affects worker behaviors, influences the speed of reaction to threats and translates into the scope and nature of effective improvement measures. Thus, worker age ranks among the key criteria for ensuring the safe performance of production tasks. The study revealed relationships between worker age and safety at workstations. Links between the two were found to be particularly pronounced among workers aged $50+$. The study's outcomes were used to define the impact of worker age on the occurrence of threats that impair the ability to perform production tasks.
\end{abstract}

\section{Introduction}

The ageing of societies in highly developed countries caused by longer lifespans and low population growth is bound to make age management central to human resource management. Between 1989 and 2013, the number of elderly people in Poland rose by close to 1.9 million. Their share in the general population climbed from $10 \%$ in 1989 to $14.7 \%$ in 2013 . The percentage of persons aged above 65 is set to continue growing in the next two decades [1].

As is equally important, elderly persons in Poland are becoming increasingly active vocationally. Eurostat data for the 55-64 age bracket show that merely $26.2 \%$ were vocationally active in 2004, 36.3\% in 2009 and as many as $42.5 \%$ in 2014. Despite the increase, Poland continues to lag behind the EU average which has recently reached $51.8 \%$. The highest rates in Europe have been reported by Scandinavian countries: $83.6 \%$ in Iceland, 74.0\% in Sweden and $72.2 \%$ in Norway. Meanwhile, the lowest rates can be found in Greece: $34.0 \%$, Slovenia: $35.4 \%$ and Croatia: $36.2 \%$. As for the rest of the world, notable examples include a solid $68.7 \%$ of people aged 55 to 64 who continue to work in Japan and $61.3 \%$ of workers in the same age group in the USA [2]. These statistics reveal a massive potential of unutilized knowledge and skills of a large segment of the 50+ population that lies fallow in Poland's economy. A number of factors contribute to this state of affairs. One of them, without a doubt, is that working

\footnotetext{
*Corresponding author: malgorzta.rembiasz@put.poznan.pl
} 
environment factors are poorly suited to the needs and capabilities of older workers, rendering them prematurely unfit for work [3].

It is increasingly critical to employ persons aged 50+. The enterprises that succeed in doing that stand to benefit from the assets of mature workers. In order to employ them, businesses need to adequately prepare their working environments. Working environment modifications to accommodate the needs of mature workers with a view to proactively ensuring their work ability should be seen as an integral part of a comprehensive strategy of age management in an enterprise [4]. Age management is crucial to companies whose labor forces are multigenerational. According to one of the earliest definitions, age management refers to: "the various dimensions by which human resources are managed within organizations with an explicit focus on ageing". [5]. Over the last dozen plus years, both the theory and practice of age management has been advancing in Western Europe, Finland, the United States and Japan. It has become the subject of hosts of scholarly and popular science publications promoting good practices in the field.

The use of an age management strategy by enterprises generates tangible benefits for both mature and younger workers. Jobs designed in compliance with ergonomic principles are likely to contribute to prolonging life expectancy and improving the health of all workers as well as increasing work efficiency in enterprises.

\section{Working conditions modification to accommodate $50+$ workers}

\subsection{Effects of age on work ability}

In ensuring conditions that enable workers to operate properly in their working environment, one should bear in mind that humans are an organization's most valuable resource. However, to utilize their potential, they need access to an environment that will allow them to operate normally. An enterprise's success or failure in enabling employees to satisfy their needs makes an enormous difference for the effects of their work $[6,7]$.

By reducing stress be establishing proper working conditions, enterprises can cut their losses, improve productivity and increase their ability to carry out tasks and run processes [8$10]$.

To ensure the capability to carry out vocational tasks, work must be designed in recognition of the capacities of persons of a specific age and in a specific environment [11,12]. It is crucial to coordinate psychological and physical effects with the ability to cope with specific situations [13].

A person's work ability declines with age. Both physical fitness and mental function become impaired. Chronic diseases and certain other health issues become exacerbated. The bodily ageing process varies widely from one individual to another depending on the factors that accelerate it or slow it down. It is very difficult to pinpoint the exact moment at which the human body begins to age and at which work ability begins to decline. Improved living conditions not only prolong life spans but also extend the time of efficient operation. Persons of the same calendar age may differ in their biological age and therefore also in their ability to function in society. Thus, to assess a person's work ability, one should define the so called functional age measured not only by the number of years one has lived but also by his/her physical and mental acumen [14].

One of the measures of the state of health that reflects a person's ability to engage in physical exertion in professional and personal life is physical functional capacity. Physical capacity defines a body's ability to perform arduous manual tasks over prolonged time and specifically to engage large muscle groups without triggering a steep increase in fatigue levels and considerable changes within the body. The measure reflects the ability to tolerate effort and 
rapidly recover from fatigue once work has ceased. With age, people lose muscular strength and circulatory and pulmonary system efficiency, which in turn hugely compromises the ability to perform strenuous physical labor [15].

The overall work ability can be measured with the work ability index (WAI), which represents a subjective seven-question survey tool. The index measures work ability on a scale from 7 to 49 . The higher the score, the greater the ability to perform work. WAI commonly classifies workers into the four ability levels of poor, moderate, good and excellent. Work ability usually declines with age although workers aged 20 to 65 commonly score good or excellent. Some $30 \%$ of the workers aged above 45 display a sharp decline in their WAI ratings. This applies to both blue and white-collar workers [15]. Notably, work ability ratios can be modified and improved by enhancing working conditions and preserving the health of workers [16].

\subsection{Modifications of working environment to fit the needs of persons aged $50+$}

The key to creating optimal working conditions is to account for such human characteristics as are vital for ensuring work ability. These are primarily physical and mental fitness, psychological qualities as well as the physical and psychological stress resulting from the nature of the work performed. For instance, mature persons are in less of a need of personal and vocational development but need more social acceptance [17].

Measures taken in keeping with a company's procedures must ensure the achievement of the adopted goals and consequently guarantee safe work performance. To identify adequate and necessary working condition improvement measures, an enterprise needs to be aware of risk levels and profiles as well as worker characteristics. By incorporating the modifications of working conditions into the guidelines [18], companies gain the ability to operate effectively under circumstances in which it is critical to avoid losses associated with failures to ensure proper working conditions to workers operating in a working environment $[19,20]$.

The desired improvement level can be achieved by properly executing corrective, correction and preventive measures that address specific risks and are sufficiently practicable, effectively ensuring the protection of specified members of the work force. Examples of actions taken in the follow-up to occupational risk assessment accounting for employee age are provided in Table 1.

In accordance with the recommendations of the International Labor Organization, mature workers require measures that [21]:

- $\quad$ remedy those conditions of work and of the working environment that are likely to hasten the ageing process,

- modify the forms of work organization and working time which lead to stress or to an excessive pace of work,

- adapt the job and its content to the worker by recourse to all available technical means and, in particular, to ergonomic principles, so as to preserve health, prevent accidents and maintain working capacity,

- provide for a more systematic supervision of the workers' state of health.

It should also be noted that the key areas of occupational activity in which particular attention needs to be paid to worker age are arduous physical work, work in a hot microclimate and shift work.

The above may be considered in view of ergonomic requirements. The aim of ergonomics is to optimize working environment stresses associated with the performance of work [12, 18, 22]. To preserve or improve the health and skills of ageing workers, care should be taken to improve their working conditions. 
Table 1. Actions taken in the follow-up to occupational risk assessment accounting for employee age $[20,22]$.

\begin{tabular}{|l|l|}
\hline \multicolumn{1}{|c|}{ Action } & \multicolumn{1}{c|}{ Employee age-related factors } \\
\hline Elimination of risks & $\begin{array}{l}\text { - ensuring conditions that allow operation on company premises, } \\
\text { including safe mobility at workstation, } \\
\text { - prevention of direct exposure to existing hazards }\end{array}$ \\
\hline $\begin{array}{l}\text { Work organization and } \\
\text { planning }\end{array}$ & $\begin{array}{l}\text { - work organization in view of workers' capacity to work at a } \\
\text { particular age }\end{array}$ \\
\hline Risk warnings & $\begin{array}{l}\text { - risk notification methods suited to the specific abilities of workers, } \\
\text { including their capacity to acquire knowledge, } \\
\text { - risk notices designed to correspond to worker experience }\end{array}$ \\
\hline Employee training & $\begin{array}{l}\text { - training conducted in recognition of reduced ability to acquire } \\
\text { knowledge and skills }\end{array}$ \\
\hline $\begin{array}{l}\text { Use of personal } \\
\text { protection equipment }\end{array}$ & $\begin{array}{l}\text { - use of personal protection equipment suited for people of a particular } \\
\text { age }\end{array}$ \\
\hline
\end{tabular}

Such an effort may be considered in terms of the working environment, which is essential for work ability. The thermal working environment forms a major factor for workers' well-being, health, work efficiency as well as occupational health and safety. Manual labor in a hot environment placed the human body under significant stress. High temperatures may cause fainting, exhaustion and even heat stroke. Numerous studies show that older people are less tolerant to heat in connection with the performance of work. Work under such conditions weakens the cardio-vascular system in 50+ workers compared to younger employees. Other observations have found that mature workers with more years of service in a hot environment behind them tend to retain physical fitness compared to other workers in the same age bracket. Such capacity is the result of heat tolerance linked to the physical fitness of the body [23].

To improve working conditions, enterprises may resort to any of a number of solutions. These include:

- flexible working time,

- job rotation,

- teams mixed in terms of age (allowing more physically demanding tasks to be performed by younger team members),

- $\quad$ opportunities to change jobs (including the securing of relevant training),

- health preservation.

Another category of solutions aimed at improving working conditions for $50+$ workers is technical in nature. Such solutions include measures that rely on:

- ergonomic principles in workstation design,

- technical means that eliminate or reduce the amount of arduous physical labor,

- $\quad$ safe technologies,

- $\quad$ proper collective and personal protection equipment suited for a particular job.

\section{Worker age and occupational accidents}

\subsection{Impact of worker age on accident statistics}

For a number of years, the relevant literature has depicted worker age ambiguously: on the one hand, such age has been presented as a factor for lowering the risk of occupational accidents while on the other, it has been associated with a greater frequency and higher severity of accidents [24]. 
According to statistics, the number of accidents at work is the highest among young and middle-aged workers. In 2014, employees aged 20 to 49 accounted for $72 \%$ of all occupational accident victims in Poland [25].

Studies have found that as workers gain experience, they also become knowledgeable about occupational safety and more capable of noticing potentially dangerous situations and responding to hazards [25-27].

National statistics provide insights into accident rates and severity in manufacturing companies. This data has been supported with the author's study.

The study has been conducted in three steel-structure manufacturers. Accident rates were examined for workers employed as metal workers, steel structure fitters, welders and welder's hands. The workers operated in a two-shift system.

Outcomes of the study are provided in Table 2.

Table 2. Accident rates in manufacturing companies by worker age.

\begin{tabular}{|c|c|c|c|c|}
\hline \multirow{2}{*}{$\begin{array}{c}\text { Manufacturing } \\
\text { company }\end{array}$} & \multicolumn{3}{|c|}{$\begin{array}{c}\text { Wumber of accidents at work between 2014 and 2015 } \\
18 \text { to 25 years }\end{array}$} & \multicolumn{2}{|c|}{$\begin{array}{c}\text { Workers aged } \\
26 \text { to 39 years }\end{array}$} \\
\cline { 2 - 5 } & Headcount & $\begin{array}{c}\text { Number of } \\
\text { accidents / accident } \\
\text { rate }\end{array}$ & Headcount & $\begin{array}{c}\text { Number of } \\
\text { accidents / accident } \\
\text { rate }\end{array}$ \\
\hline Enterprise A & 16 & $2 / 0.125$ & 18 & $1 / 0.056$ \\
\hline Enterprise B & 19 & $1 / 0.053$ & 19 & $3 / 0.158$ \\
\hline Enterprise C & 21 & $3 / 0.143$ & 22 & $2 / 0.091$ \\
\hline
\end{tabular}

\begin{tabular}{|c|c|c|c|c|}
\hline \multirow{2}{*}{$\begin{array}{c}\text { Manufacturing } \\
\text { company }\end{array}$} & \multicolumn{3}{|c|}{$\begin{array}{c}\text { Workers aged } \\
\text { 40 to 50 years }\end{array}$} & \multicolumn{2}{c|}{$\begin{array}{c}\text { Workers aged } \\
\text { above 50 years }\end{array}$} \\
\cline { 2 - 5 } & Headcount & $\begin{array}{c}\text { Number of } \\
\text { accidents / accident } \\
\text { rate }\end{array}$ & $\begin{array}{c}\text { Number of } \\
\text { Headcount }\end{array}$ & $\begin{array}{c}\text { accidents / accident } \\
\text { rate }\end{array}$ \\
\hline Enterprise A & 10 & $1 / 0.100$ & 9 & $3 / 0.333$ \\
\hline Enterprise B & 7 & $2 / 0.286$ & 8 & $2 / 0.250$ \\
\hline Enterprise C & 13 & $2 / 0.154$ & 11 & $3 / 0.273$ \\
\hline
\end{tabular}

The study outcomes (accident rates) are shown in Figure 1.

The above accident statistics show clearly that workers above 50 years of age are the most likely to become involved in occupational accidents. The trend applies regardless of the professional training given workers have received to prepare them for the jobs [3, 20]. However, worker age can also be seen as a mitigator of accident likelihood. To benefit from this influence, employers need to design work properly and make best use of the potential offered by older individuals.

A large proportion of occupational accidents are caused by humans. It seems that the advice and watchful eye of senior colleagues can offset the careless tendencies of younger workers which often result from lack of knowledge and recklessness in the face of hazards.

This said, it should nevertheless be noted that the occupational accidents affecting older workers are more likely to be severe. The ratio of fatal accidents at work per 1000 workers is the lowest among young employees and grows almost linearly with the age of victims to peak in the 60 to 64 age bracket. Such a high frequency of fatal accidents among mature workers may be the result of declines in their physical capacity due to age, among other factors. Furthermore, the time a victim needs to fully recover from an accident also grows with employee age [27-29]. 


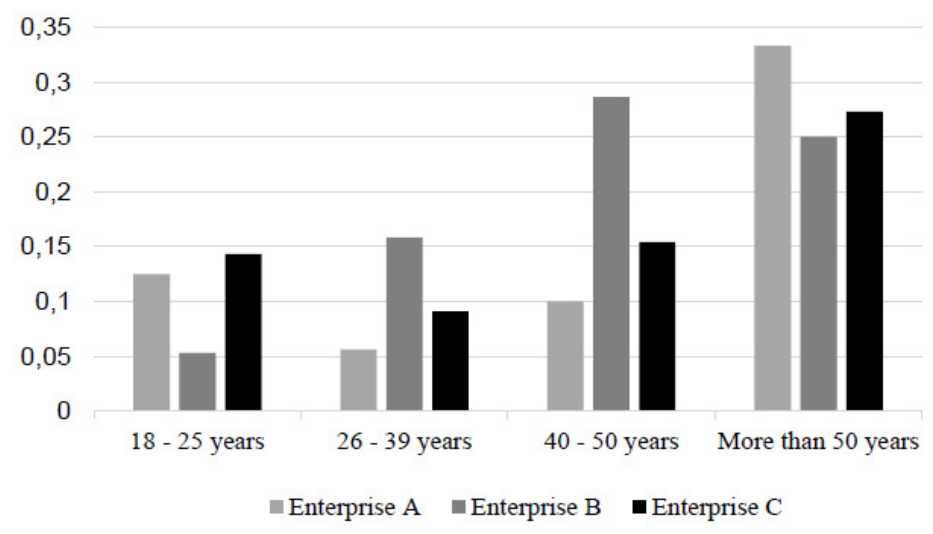

Fig. 1. Accident rates as a function of worker age.

Research suggests that preventive measures should rely on differentiated means and channels to reach potential accident victims and provide them with different types of information depending on their profiles. While electronic information channels work are embraced readily by young people, older workers are best targeted with printed materials as well as campaigns in the traditional news media (the press, radio, television) and provided with information meetings on workplace risks [30].

\subsection{Sample age management improvement measures}

In many business organizations, job security depends heavily on the management measures taken in specific fields. Such fields include employee age and work experience. An organization's ability to develop a comprehensive age management strategy depends on a number of factors which influence the measures it undertakes. The key factors of this kind include the awareness of the need for such measures.

The most critical age management measures taken by companies are to [31]:

- improve employee competencies by designing individual training schemes for workers to equip them with the knowledge they need in their specific jobs,

- offer a broader spectrum of flexible forms of employment that includes part-time employment opportunities for 50+ workers,

- improve work comfort,

- improve workers' physical fitness and reduce number of tasks causing excessive fatigue.

Such measures may substantially improve working conditions and work organization as well as boost productivity and the quality of job performance.

Good management practices may inspire the design of age management strategies that reflect the specific operating profiles of enterprises. Businesses looking to achieve lasting improvements should therefore adopt these concepts more broadly. Examples of such measures are provided in Table 3. 
Table 3. Sample age management measures [32-34].

\begin{tabular}{|l|l|l|}
\hline Business field & $\begin{array}{l}\text { Improvement } \\
\text { area }\end{array}$ & \multicolumn{1}{c|}{ Sample measure } \\
\hline $\begin{array}{l}\text { Waste treatment } \\
\text { company }\end{array}$ & $\begin{array}{l}\text { Ergonomics, } \\
\text { improvement } \\
\text { of working } \\
\text { conditions }\end{array}$ & $\begin{array}{l}\text { To protect older employees from excessive fatigue, the } \\
\text { company adopted standard P90, which prohibits assigning } \\
\text { employees to jobs which exceed the physical capacities of } \\
90 \% \text { of the labor force in an average worker group of a } \\
\text { specific age. Furthermore, to reduce physical loads, } \\
\text { technical solutions were adopted that ease work-related } \\
\text { strain. }\end{array}$ \\
\hline $\begin{array}{l}\text { Manufacturer of } \\
\text { would products }\end{array}$ & $\begin{array}{l}\text { Professional } \\
\text { improvement } \\
\text { of workers }\end{array}$ & $\begin{array}{l}\text { Towards the end of their on-the-job training, interns are } \\
\text { employed by the company and then gradually inducted to } \\
\text { perform tasks of growing complexity. The company has } \\
\text { developed a competence improvement strategy that allows } \\
\text { it to benefit from the knowledge of retiring workers (ensure } \\
\text { knowledge transfers). To that end, the employer has offered } \\
\text { advanced employee training, internal workshops, external } \\
\text { improvement opportunities, etc. }\end{array}$ \\
\hline $\begin{array}{l}\text { Trading } \\
\text { company }\end{array}$ & $\begin{array}{l}\text { Ensuring } \\
\text { health and } \\
\text { well-being } \\
\text { The company offers workshops that increase the awareness } \\
\text { sick leave. By reducing stress, raising creativity levels and } \\
\text { sick limpact on employee propensity to go on } \\
\text { increasing loyalty, the enterprise has been able to boost } \\
\text { productivity. The company also reminds its workers that } \\
\text { each of them is responsible for their own health. }\end{array}$ \\
\hline
\end{tabular}

By adopting comprehensive age management strategies, business organizations make better use of their existing human resources. This results mainly from ensuring working conditions that reflect worker age and capabilities and facilitating collaboration among employees of different ages.

\section{Conclusions}

The high proportion of older people in the overall population results from contemporary socio-economic processes and should be seen as more of a challenge than a threat.

Ergonomically-compliant work organization is likely to prolong worker life spans and improve their health. The design of workstations and physical working environments in keeping with ergonomic principles generates measurable benefits for workers (especially the mature ones) and employers alike. These include reduced work fatigue, fewer cases of work-related diseases and occupational accidents and better work efficiency. Thus, ergonomic requirements address the primary objective of any enterprise (as postulated by economic sciences), which is to maximize profit.

Job satisfaction and work ability are particularly crucial for older workers who face a number of limitations in the performance of work that come with age. Therefore, employers need to take a number of measures that mitigate the impact of such limitations. By employing 50+ workers, an organization benefits from their strengths, thereby adding to its own capacities. One of the side benefits of such employment is greater loyalty of younger workers who grow to perceive their jobs as secure and associate them with career opportunities.

Employees of all ages, including those in preretirement age, can be highly efficient. The only prerequisite for their efficiency is to modify the nature of their work to best fit their capabilities (which include their state of health and predispositions). Such modifications will allow an enterprise to make better use of the worker's potential and increase their motivation to work. 
"Good practices" tend to inspire the design of age management strategies that reflect the specific profiles of a company's operations. Organizations that strive to ensure lasting growth should therefore engage in this area of improvement.

In macroeconomic terms, modifying working conditions to the needs of $50+$ employees is a way to retain persons aged above 50 in employment. Many mature individuals would like to continue to put their vocational skills and experience to good use. Keeping persons aged above 50 professionally active is certainly a way to ensure better compliance with the principles of knowledge-based economy and to further a country's economic growth. A company's management should be aware of the need to employ older workers, ensure they can function properly in the working environment and make appropriate use of their strengths.

\section{References}

1. Sytuacja demograficzna osób starszych i konsekwencje starzenia się ludności Polski w świetle prognozy na lata 2014-2050 (GUS, Warszawa 2014)

2. EUROSTAT, http://ec.europa.eu/eurostat/statistics-explained/index.php/Employment_ statistics/pl (date of access: 01.12.2015)

3. M. Rembiasz, A. Górny, Zeszyty Naukowe Politechniki Poznańskiej, Organizacja i Zarządzanie, 65, 115-126 (2015)

4. M. Rembiasz, Zeszyty Naukowe Uniwersytetu Szczecińskiego, 849, 155-167 (2015)

5. A. Walker, Combating Age Barriers in Employment. European Research Report (European Foundation for the Improvement of Living and Working Conditions, Dublin 1997)

6. A. Górny, M. Rembiasz, Praca i Zabezpieczenie Społeczne, 8, 98-110 (2015)

7. A. Kawecka-Endler, B. Mrugalska, Human-Computer Interaction: Applications and Services, III, 8512, 700-709 (2014)

8. M. Butlewski, Technologies, Materials. Int. Virtual J., VII (11), 24-28 (2013)

9. A. Górny, Foundation of Control and Management Sciences, 11, 127-138 (2008)

10. B. Mrugalska, Need of safety integration in robust design, In: P. Vink (ed.), Advances in social and organizational factors, 260-266 (AHFE 2014)

11. M. Rembiasz, Zeszyty Naukowe Uniwersytetu Szczecińskiego, 809, 499-508 (2014)

12. A. Górny, Ergonomics Aspects of CSR in System Shaping the Quality of Work Environment, In: P. Vink (Ed.), Advances in Social and Organizational Factors, 541550 (AHFE 2012)

13. D. Efraty, M. J. Sirgy, Social Indicators Research, 22(1), 31-47 (1990)

14. J. Bugajska, T. Makowiec-Dąbrowska, E. Wągrowska-Koski, Medycyna Pracy, 60, 16 (2010)

15. J. Bugajska, E. Łastowiecka, Int. J. of Occupational Safety and Ergonomics, 12, 231240 (2006)

16. J. Ilmarinen, Wspieranie aktywnego starzenia się $w$ miejscu pracy, https://osha.europa.eu/pl (date of access: 12.07.2014)

17. G. Richenhagen G., Personalführung, 8, 44-51 (2007)

18. M. Butlewski, E. Tytyk, K. Wróbel, Macroergonomic model of quality of life of elderly employees for design purposes, In: P. Vink (Ed.), Advances in Social and Organizational Factors, 252-260 (AHFE 2014)

19. P. F. Drucker, Skuteczne zarzadzanie: zadania ekonomiczne a decyzje zwiazane z ryzykiem (PWN, Warszawa 1976)

20. A. Górny, Zarządzanie ryzykiem zawodowym (Wydawnictwo Polietchniki Poznańskiej, Poznań 2011) 
21. Recommendation concerning Older Workers (No. 162, 66th ILC session (23 Jun 1980) (International Labour Organization (ILO), Geneva 1980)

22. A. Górny, The Elements of Work Environment in the Improvement Process of Quality Management System Structure, In: W. Karwowski, G. Salvendy (Eds.), Advances in Human Factors, Ergonomics, and Safety in Manufacturing and Service Industries, 599-606 (AHFE 2011)

23. T. Makowiec-Dąbrowska i in., Zawodowe i pozazawodowe determinanty zdolności do pracy starszych pracowników, Raport końcowy PCZ 21-21, Zadanie 8 (CIOP-PIB, Warszawa 2004)

24. L. Laflamme, E. Menckel, Safety Science, 21, 145-161 (1995)

25. Wypadki przy pracy w 2014 roku (GUS, Warszawa 2015)

26. S. A. Gyekye, S. Salminen, JOSE, 16(4), 441-443 (2010)

27. Analiza przyczyn i skutków wypadków przy pracy w latach 2008 - 2011 ze szczególnym uwzględnieniem obszarów, w których wypadki przy pracy powoduja największe straty ekonomiczne $i$ spoteczne oraz określenie rekomendacji dotyczacych dziatań prewencyjnych (RESOURCE 2012)

28. S. Ordysiński, Bezpieczeństwo Pracy, 7, 22-26 (2013)

29. A. Górny, M. Rembiasz, Zeszyty Naukowe Politechniki Poznańskiej, Organizacja i Zarządzanie, 64, 49-64 (2015)

30. A. Kwiatkiewicz, Analiza dobrych praktyk dotyczacych zarzadzania wiekiem w polskich przedsiębiorstwach - studium przypadku (PARP, Warszawa 2010)

31. M. Rembiasz, Zeszyty Naukowe Uniwersytetu Szczecińskiego, 848, 139-148 (2015)

32. J. Litwiński, Opis dobrych praktyk dotyczacych zarzadzania wiekiem $w$ przedsiębiorstwach polskich oraz innych krajów UE (PARP, Warszawa 2010)

33. European Observatory of Working Life, http://www.eurofound.europa.eu/areas/ populationandsociety /cases/si004.htm (date of access: 01.05.2015)

34. M. Rembiasz, Aktywność zawodowa osób w wieku emerytalnym - wybrane problemy, In: M. Szczepański (Ed.), Pension reforms - comparison and evaluation, 329-339 (Poznan University of Technology, Pozanń 2013) 